HANS J. MORGENTHAU

Tekst został przetłumaczony na postawie: H. J. Morgenthau, The Dilemmas of Freedom, [w: ] "The American Political Science Review”, Vol. 51, No. 3, September 1957, ss. 714-723. Serdecznie dziękujemy Cambridge University Press, wydawcy czasopisma, za zgodę na publikację tłumaczenia.

\title{
Dylematy wolności*
}

Dodczas Wojny Secesyjnej, która była wojną o wolność w prawdziwszym sensie niż większość wojen, które zostały tak nazwane, Abraham Lincoln odsłonił podstawy dylematu, który sprawiał trudności w filozoficznym rozumieniu wolności i który ukazał, że zawsze pozostawało coś do życzenia w jej politycznej realizacji. 18 kwietnia 1864 roku Lincoln wygłosił zwięzłe i skromne przemówienie do tłumu zgromadzonego podczas Sanitary Fair ${ }^{1}$ w Baltimore.

„Świat nigdy nie miał dobrej definicji słowa wolność - powiedział a Amerykanie, właśnie teraz, bardzo jej potrzebują. Wszyscy opowiadamy się za wolnością, ale używając tego samego słowa, nie wszyscy mamy na myśli tę samą rzecz. W niektórych [definicjach] słowo wolność może oznaczać robienie tego, co się podoba przez każdego człowieka i wynik jego pracy; w innych natomiast, to samo słowo może oznaczać dla niektórych [ludzi] robienie z innymi tego, co im się podoba i wytwór pracy tych innych [ludzi]. Oto dwie, nie tylko odmienne, ale i rozbieżne rzeczy określane tą samą nazwą wolność. Wynika z tego, że każda z tych rzeczy jest przez odmienne stronnictwa nazywana dwoma odmiennymi i rozbieżnymi terminami - wolność i tyrania.

Pasterz chroni owcę przed wilkiem, za co ona jest mu wdzięczna jako swojemu wybawcy, podczas gdy za ten sam czyn, wilk oskarża pasterza o niszczenie wolności, zwłaszcza jeśli owca była czarna. Oczywiście owca

Pełen tekst tłumaczenia dostępny jest $\mathrm{w}$ drukowanej wersji pisma. Referat został zaprezentowany po raz pierwszy podczas Conference on the Essential of Freedom, która odbyła się w Kenyone College, w kwietniu 1957 roku.

Rodzaj dobroczynnych targów [przyp. tłum.]. 
i wilk nie są zgodni, co do definicji słowa „wolność” i dokładnie ta sama różnica zdań panuje obecnie wśród nas, istot ludzkich, nawet na Północy, zapewniających o miłości do wolności. Dlatego procesy, jakie widzimy, w wyniku których tysiące osób dziennie wyzwala się spod jarzma niewoli, okrzyknięte są przez niektórych jako postęp wolności, a opłakane przez innych jako jej całkowitą destrukcję.

Wolność polityczna posiada dwa odmienne i rozbieżne znaczenia w zależności od tego, czy myślimy o posiadaczu władzy politycznej czy też o jej poddanym. Wolność dla posiadacza władzy oznacza możność wykorzystania dominacji politycznej, wolność dla poddanego oznacza nieobecność tejże dominacji. Nie tylko te dwie koncepcje wolności logicznie wykluczają się wzajemnie, ale są one również niezdolne do faktycznej koegzystencji w obrębie jakiejkolwiek sfery działań. Jedna może być zrealizowana tylko kosztem drugiej i, co więcej, im mniej jest pierwszej, tym większa przeszkoda w zaistnieniu drugiej.

Pojęcie wolności, rozpatrywane z punktu widzenia władcy i jego poddanego, jest sprzeczne. Ambiwalentne jest również to, że większość członków społeczeństwa nie jest po prostu jednym bądź drugim, władcą lub poddanym, ale obydwoma równocześnie. $B$ jest władcą $C \mathrm{w}$ jednym przypadku, jak również poddanym $\mathrm{A} w$ drugim, a $\mathrm{C}$, kolejno, jest władcą $\mathrm{D} \mathrm{w}$ trzecim przypadku i tak dalej. Większość ludzi gra wiele ról w odniesieniu do władzy politycznej, podporządkowując jej ludzi i będąc również jej podporządkowywanym przez innych. Kiedy żądają dla siebie wolności, co też mają na myśli: wolność dominacji nad innymi czy wolność od ich dominacji? Być może mają na myśli jedno, być może drugie, a może obydwa. Ta ambiwalencja stwarza nieuchronnie ciąg nieporozumień, manifestując się w charakterystyczny sposób w ideologiach, które racjonalizują i usprawiedliwiają wolność do dominacji w pojęciach wolności od dominacji.

Wynika z tego, że powszechna i absolutna wolność jest pojęciem wewnętrznie sprzecznym. W sferze politycznej wolność jednostki istnieje zawsze kosztem braku wolności kogoś innego. Władca może zachować swoją wolność tylko kosztem wolności tych, którzy są mu poddani, ci drudzy mogą być wolni tylko, jeśli sprawią, żeby władca poświęcił swoją wolność. (...) 